\title{
Chesapeake Bay Impact Structure Deep Drilling Project Completes Coring
}

\author{
by Gregory S. Gohn, Christian Koeberl, Kenneth G. Miller, Wolf Uwe Reimold, \\ and the Scientific Staff of the Chesapeake Bay Impact Structure Drilling Project
}

doi:10.2204/iodp.sd.3.07.2006

\section{Introduction}

The Chesapeake Bay Impact Structure Deep Drilling Project (CBIS Project) completed its coring operations during September-December 2005 and April-May 2006. Cores were collected continuously to a total depth of $1766 \mathrm{~m}$. The recovered section consists of $1322 \mathrm{~m}$ of impactites beneath $444 \mathrm{~m}$ of post-impact continental shelf sediments.

The CBIS Project is a joint venture of the International Continental Scientific Drilling Program (ICDP) and the U.S. Geological Survey (USGS). Project activities began with a planning workshop in September 2003 attended by sixtythree scientists from ten countries. Field operations began with site preparation in July 2005, and coring began in September 2005. Drilling, Observation and Sampling of the Earth's Continental Crust (DOSECC) was the general contractor for the drilling operations throughout 2005.

Buried at shallow to moderate depths beneath continental margin sediments in southeastern Virginia, U.S.A. (Fig. 1), the Late Eocene Chesapeake Bay impact structure is among the largest and best preserved of the known impact structures on Earth (Poag et al., 2004). It is the second largest

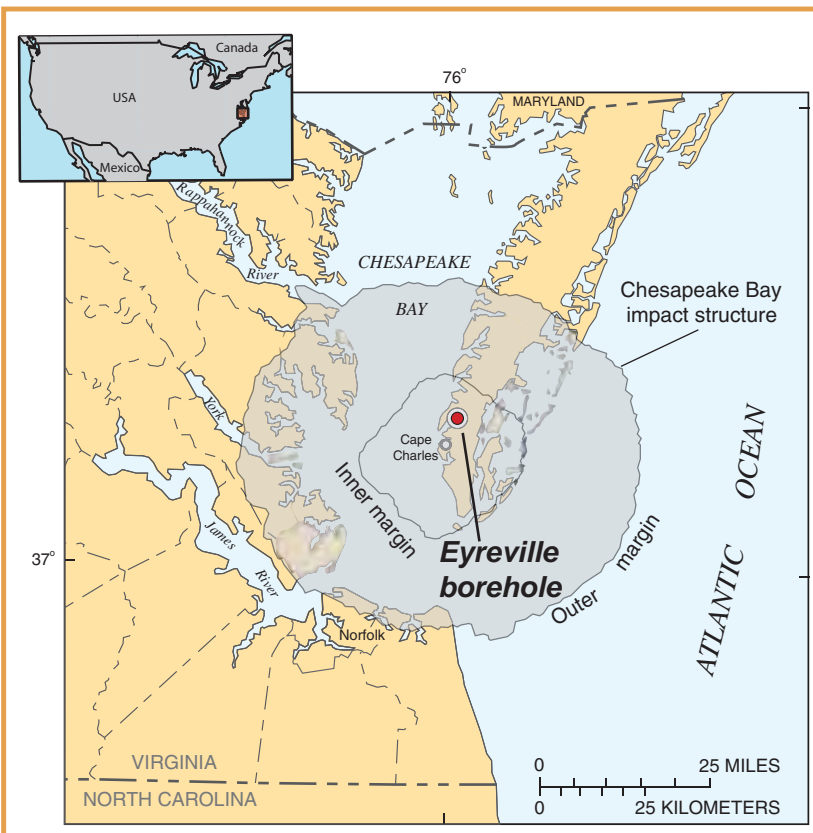

Figure 1. Map showing location of Eyreville drilling site in Chesapeake Bay impact structure. among only a handful of known impact structures that formed in a marine setting, surpassed in size only by the Chicxulub structure on the Yucatan Peninsula, Mexico, the subject of an ICDP drilling project in 2001-2002 (see related Web link at the end of this article).

The Chesapeake Bay impact structure is an inviting target for borehole studies of impact phenomena. This structure is perhaps unique in presenting a drilling target where the effects of an impact on a shallow-marine, rheologically layered, silicic target can be investigated and where the potential exists to recover a complete section of core through the impact-breccia fill of a crater and through the post-impact sedimentary cover. Also, it is the source of one of only four known tektite strewn fields, the North American tektite strewn field (Koeberl et al., 1996).

The Chesapeake Bay impact structure consists of a 38-km-wide, strongly and deeply deformed central zone surrounded by a shallower outer zone of sediment collapse known as the annular trough. Collectively, these two zones have a diameter of about $85 \mathrm{~km}$ and a distinctive shape that is generally referred to as an "inverted sombrero" (Fig. 2).

This project also provided an opportunity to study the history of sea-level and climate, the effects of the impact on the regional hydrologic framework and resources, and the ancient and modern microbiota of a deep subsurface environment. The post-impact upper Eocene to Pleistocene sediments that cover the impact structure consist primarily of fine-grained marine sections that document the middle to late Cenozoic sea level history, stratigraphic sequences, and climatic variability of the Mid-Atlantic segment of the eastern U.S. continental margin. The stratigraphic data will be backstripped to account for the effects of sediment loading, compaction, paleowater depth, and basin subsidence. Comparison with results from boreholes outside of the crater (e.g., Miller et al., 2005) will allow us to quantify the effects of tectonics and global sea level.

The presence of salty groundwater throughout the impact structure is of significant interest to hydrologists studying the future availability of fresh water in the densely populated urban corridor located along the south and southwestern margins of the structure. Topics of immediate interest that are addressed by the deep borehole include the physical disruption of the aquifer system by the impact, the 
entrainment and alteration of Eocene seawater, and the effects of the impact-related hydrothermal system and later diagenesis on groundwater chemistry. The cores were sampled to determine groundwater chemistry and hydrogeologic properties of the sediments and rocks.

The CBIS Project also provided an opportunity for studying the deep biosphere in a variety of environmental and paleoenvironmental settings to elucidate such

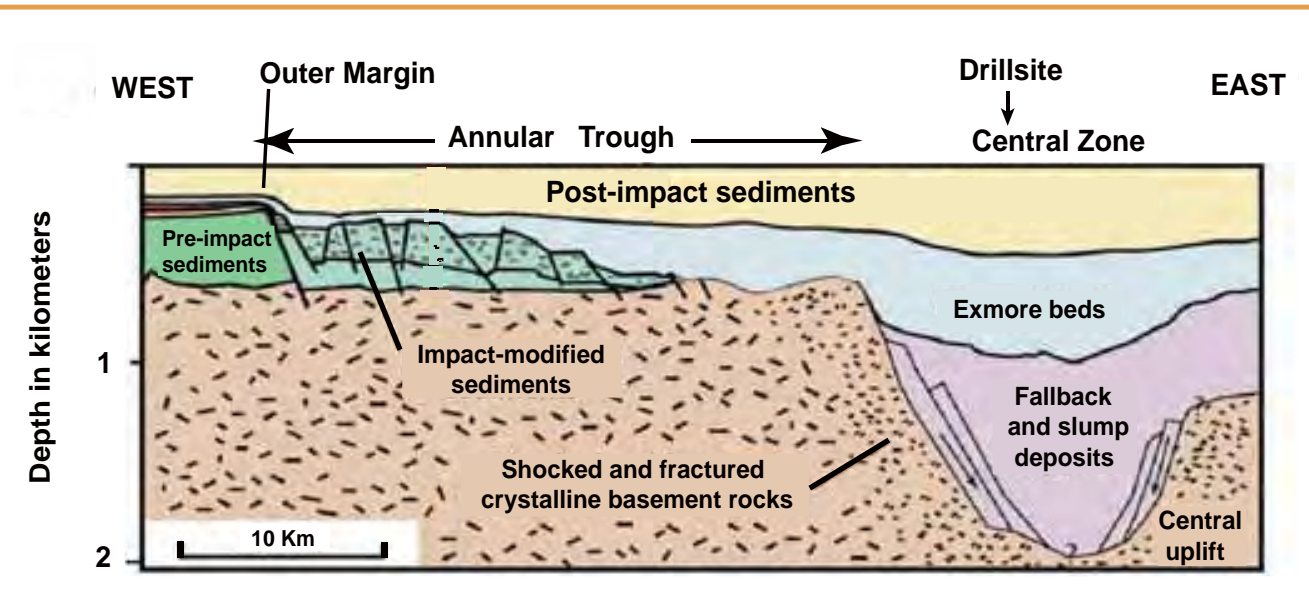

Figure 2. Schematic radial cross section showing half of "inverted sombrero" shape of Chesapeake Bay impact structure. Modified from Horton et al., 2005.

basic parameters as subsurface microbial diversity and abundance. The ecology of terrestrial hydrothermal systems related to impact events is essentially unstudied compared to those related to vol-canic activity. The long history of impact cratering throughout the solar system suggests the possibility that impact-related hydrothermal systems might be common habitats on other solar system bodies and highlights the need for studying similar systems on Earth. Cores from the post-impact section provide an opportunity to study fossil microbial traces at significant depths within geologically young marine sediment. Microbiota samples were collected from the three Eyreville cores using appropriate anti-contamination protocols, including halon gas and microbeads as tracers in the drilling mud during core retrieval.

\section{Drilling Strategy}

The drilling site is located on private land, known locally as the Eyreville Farm (Fig. 3), in Northampton County, Virginia, about $7 \mathrm{~km}$ north of the town of Cape Charles (Fig. 1). The drilling strategy was designed to sample continuously the entire section of post-impact sediments and craterfilling impactites, and a short section of autochthonous breccias in the crater floor, to a depth of about $2.2 \mathrm{~km}$. Problems with lost mud circulation, trapped drill rods, and locally slow penetration rates in the impactite section ultimately limited the total depth to $1.766 \mathrm{~km}$.

Three boreholes were drilled at the Eyreville site (Table 1) in several stages from late July 2005 to early May 2006. Somerset Drilling, Inc. conducted rotary drilling (no coring) to a depth of about $128 \mathrm{~m}$ and installed large-diameter steel casing to a depth of $125 \mathrm{~m}$ in the Eyreville A borehole. The principal contract driller, Major Drilling America, deepened this borehole to a total depth of $940.9 \mathrm{~m}$ using a wireline coring rig. Expanding and sliding red clay sections caused repeated problems during reaming attempts, and the bit eventually deviated from the original hole at a depth of 737.6 $\mathrm{m}$. As a result, duplicate cores were collected between depths of $737.6 \mathrm{~m}$ and $940.9 \mathrm{~m}$. The new borehole below the deviation point at $737.6 \mathrm{~m}$ was designated as the Eyreville B borehole (Table 1).

Coring proceeded in the Eyreville B borehole to a depth of $1100.9 \mathrm{~m}$, where the bit was deliberately stuck within a section of granite and the drill rods were left in the hole to serve as casing against the red clays. Drilling then resumed in the Eyreville B borehole with a narrower sampling system and continued without major problems to the final depth of $1766.3 \mathrm{~m}$.

Project members from the USGS, Rutgers University, and the Virginia Department of Environmental Quality returned to the Eyreville site in April 2006 and cored a third hole, Eyreville C, to a total depth of $140.2 \mathrm{~m}$ (Table 1), using a truck-mounted wireline coring rig. As a result, the upper part of the post-impact sedimentary section was sampled in Eyreville $\mathrm{C}$ to complement the deeper section of post-impact sediments recovered in Eyreville A.

Limited suites of geophysical logs such as natural gamma ray, spontaneous potential, and resistivity were acquired from the upper $125 \mathrm{~m}$ of the Eyreville A borehole and from the Eyreville $\mathrm{C}$ borehole. Unfortunately, planned interim and final geophysical logging activities for the deeper section of the combined A and B boreholes were compromised because of trapped drill rods, logging equipment malfunctions, and bridging of the open hole after the rods were removed. Three logs were acquired after the coring was completed. The USGS logger collected a natural gamma log and a temperature log for nearly the entire length of the combined $A$ and B holes. A temperature log also was collected using a probe

Table 1: Cored sections in Eyreville boreholes.

\begin{tabular}{|l|l|}
\hline A: & 125.6 to $591.0 \mathrm{~m}, \mathrm{PQ}$ core (85.0 mm diameter) \\
\hline B: & 591.0 to $940.9 \mathrm{~m}, \mathrm{HQ}$ core (63.5 mm diameter) \\
\hline & 737.6 to $1100.9 \mathrm{~m}, \mathrm{HQ}$ core (63.5 mm diameter) \\
\hline C: & 1100.9 to $1766.3 \mathrm{~m}, \mathrm{NQ}$ core (47.6 mm diameter) \\
\hline & 0 to $140.2 \mathrm{~m}, \mathrm{HQ}$ core (63.5 mm diameter)
\end{tabular}


from Karlsruhe University, Germany. Additional temperature logs were collected in the A-B borehole in May 2006 using the Karlsruhe temperature logger. Supplementary measurements of petrophysical properties using a multisensor core logger are planned.

\section{Preliminary Results}

The 1322-m-thick section of impactites consists of four major lithologic units (Gohn et al., 2006; Reimold et al., 2006). The lowest unit, probably representing locally brecciated bedrock, consists of about $216 \mathrm{~m}$ of mica schist and pegmatite with minor gneiss and a few impact-generated breccia veins (Table 2). About $179 \mathrm{~m}$ of suevitic and lithic impact breccias (Fig. 4) overlie the schists and pegmatites and underlie a 275-m-thick megablock, or megablocks, of granitic rock. The upper part of the impactite section (652 m) consists of sedimentary breccia that contains clasts of sediment and crystalline rock. A wide variety of mineralogic, petrologic, geochemical, radiometric, and structural studies of the impactite section are now underway.

The huge unexpected megablock of granite encountered at Eyreville presents an example of challenging decision making during the drilling of large impact structures. The coring of hundreds of meters of granite across numerous days suggested that the crater floor already had been penetrated at an unexpectedly shallow depth according to geophysical data. However, it was decided to continue drilling, and ultimately the base of the granite was reached, below which a section of suevitic breccias was encountered (Table 2), confirming that the block had been transported a great distance during the impact event.

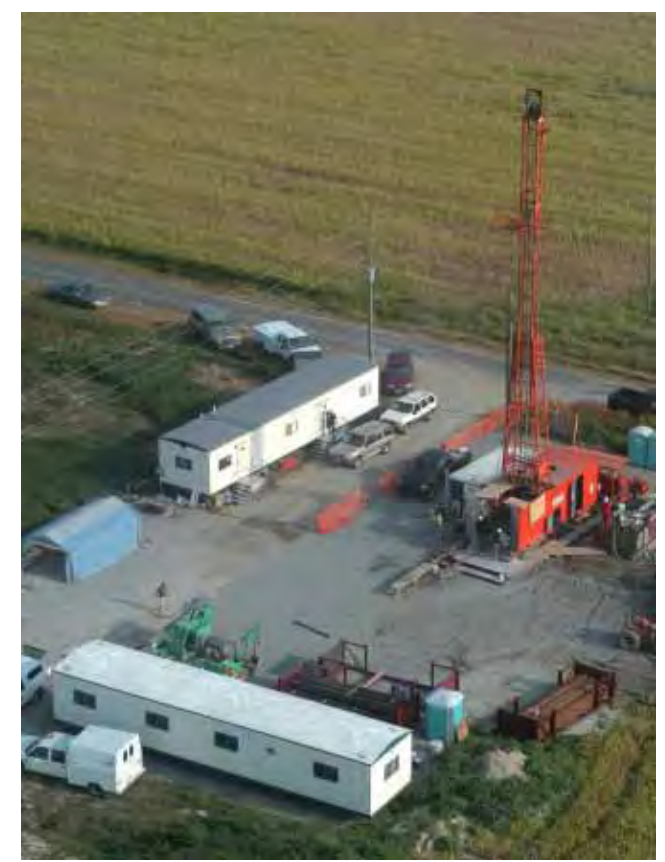

Figure 3. Low-altitude aerial photograph of Eyreville drilling site.
The 444-m-thick section of post-impact sediments consists of Upper Eocene, Oligocene, Miocene, and Pliocene marine sediments and Pleistocene paralic sediments. Lithologic (including grain size, composition, and clay mineralogy), sequence stratigraphic, biostratigraphic (including studies of calcareous nannofossils, foraminifers, dinocysts, diatoms, and pollen), and chemostratigraphic (including $\mathrm{Sr}$ isotopes and stable isotopes) studies are ongoing. Preliminary results indicate thick Middle Miocene to Pliocene and Upper Eocene deposits, with relatively thin Lower Miocene and Oligocene sections.

\section{International Sampling Party}

The research phase of the project began in March 2006 with an international sampling party. About thirty project scientists from seven countries marked about 1800 samples for future study. Popular targets for sampling were the suevitic and lithic impact breccias and the short section that records the transition from late syn-impact to post-impact sedimentation and biotic-recovery. The cutting and shipping of samples took place from April to June 2006.

\section{Acknowledgements}

The planning workshop for the CBIS project was funded by the ICDP and hosted by the USGS. A resulting funding proposal to ICDP was accepted in late 2004, and additional drilling funds were authorized by the USGS. The National Aeronautics and Space Administration (NASA) Science Mission Directorate, the ICDP, and the USGS provided important supplementary drilling funds in NovemberDecember 2005 that permitted coring of the deeper part of the impact structure. Studies of post-impact sediments were supported by the U.S. National Science Foundation (NSF), Earth Science Division, Continental Dynamics Program.

We thank DOSECC for their excellent handling of the field operations, and Major Drilling America for their professionalism and the successful completion of the deep coring. We also thank the Buyrn family for the use of their land for the drilling operations and for their enthusiastic interest in the project. We thank the ICDP, the USGS, the NASA Science Mission Directorate, and the NSF for funding the drilling operations. Finally, the principal investigators thank the international group of geologists and technicians for their dedication and hard work at the drilling site. 


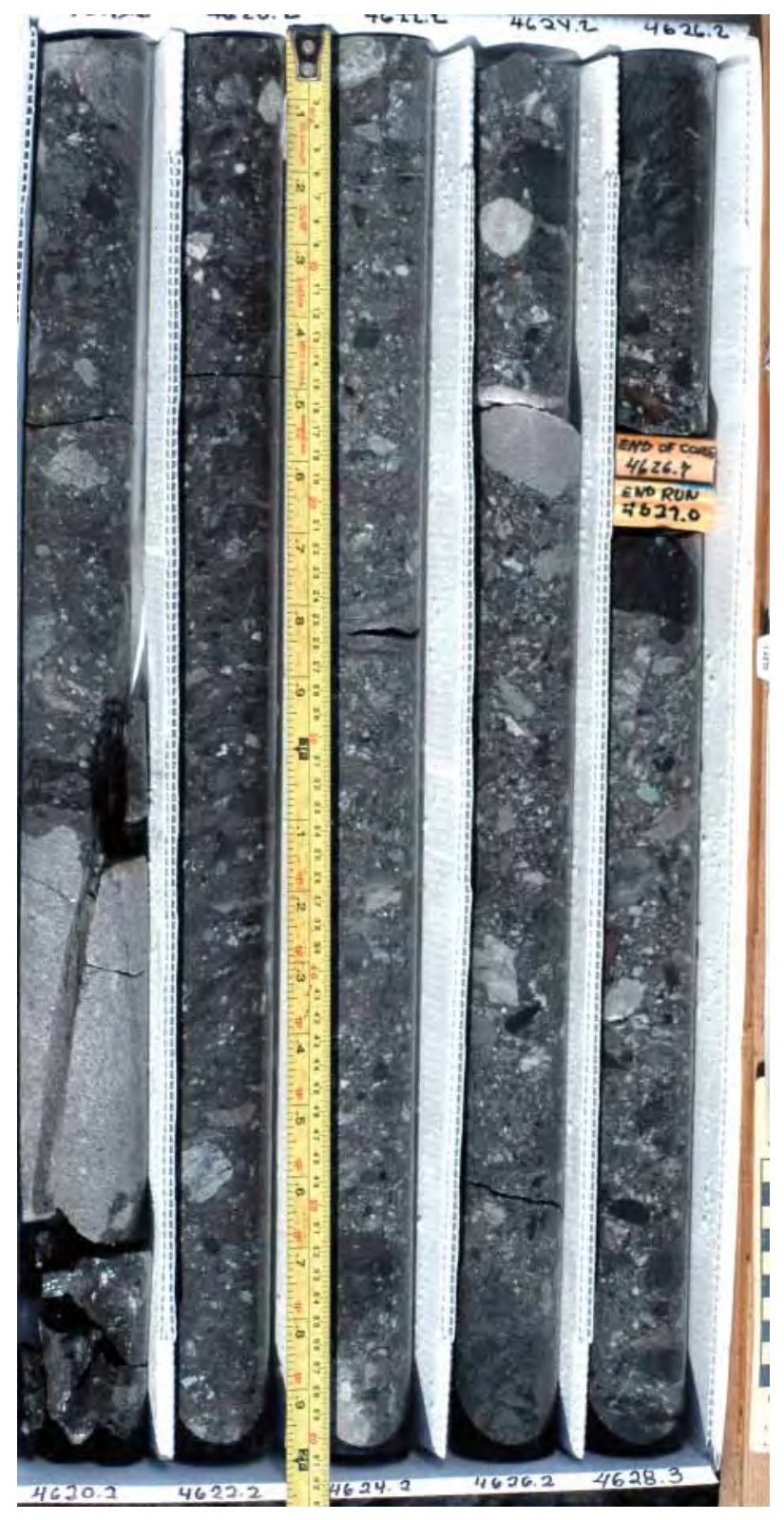

Figure 4. Suevitic and lithic breccia from Eyreville B borehole.

\section{CBIS Drilling Site Scientific Staff}

O. Abramov, W. Aleman Gonzalez, N. Bach, A. Blazejak, J. Browning, T. Bruce, C. Budet, L. Bybell, E. Cobbs, Jr., E. Cobbs, III, C. Cockell, B. Corland, C. Durand, H. Dypvik, J. Eckberg, L. Edwards, S. Eichenauer, T. Elbra, A. Elmore, J. Glidewell, G. Gohn, A. Gronstal, A. Harris, P. Heidinger, S.-C. Hester, W. Horton, K. Jones, A. Julson, D. King, J. Kirshtein, C. Koeberl, T. Kohout, T. Kraemer, D. Kring, A. Kulpecz, M. Kunk, D. Larson, U. Limpitlaw, M. Lowit, N. McKeown, P. McLaughlin, K. Miller, S. Mizintseva, R. Morin, J. Morrow, J. Murray, J. Ormö, R. Ortiz Martinez, L. Petruny, H. Pierce, J. Plescia, D. Powars, A. Pusz, D.B. Queen, D.G. Queen, U. Reimold, W. Sanford, E. Seefelt, J. Self-Trail, D. Vanko, M. Voytek, B. Wade, J. Wade, D. Webster, B. Zinn, and V. Zivkovic.

\section{References}

Gohn, G.S., Koeberl, C., Miller, K.G., Reimold, W.U., Browning, J.V., Cockell, C.S., Dypvik, H., Edwards, L.E., Horton, J.W., Jr., McLaughlin, P.P., Ormö, J., Plescia, J.B., Powars, D.S., Sanford, W.E., Self-Trail, J.M., and Voytek, M.A., 2006, (abstract). 37th Lunar and Planetary Science Conference, Houston, Texas, U.S.A., 13-17 March 2006. abstract no. 1713. http://www.lpi.usra.edu/meetings/lpsc2006/pdf/ 1713.pdf.

Horton, J.W., Jr., Powars, D.S., and Gohn, G.S., 2005. Studies of the Chesapeake Bay impact structure - Introduction and discussion. U.S. Geological Survey Professional Paper, 1688: A1-A24.

Koeberl, C., Poag, C.W., Reimold, W.U., and Brandt, D., 1996. Impact origin of Chesapeake Bay structure and the source of North American tektites. Science, 271:1263-1266.

Miller, K.G., Kominz, M.A., Browning, J.V., Wright, J.D., Mountain, G.S., Katz, M.E., Sugarman, P.J., Cramer, B.S., ChristieBlick, N., and Pekar, S.F., 2005. The Phanerozoic record of global sea level change. Science, 310:1293-1298, doi:10.1126/science.1116412.

Poag, C.W., Koeberl, C., and Reimold, W.U., 2004. Chesapeake Bay Crater: Geology and Geophysics of a Late Eocene Submarine Impact Structure. Impact Studies, Volume 4: Heidelberg, (Springer-Verlag) 522pp.

Reimold, W.U., Gohn, G.S., Koeberl, C., and Miller, K.G., 2006. Report on the 2005 ICDP-USGS deep corehole in the Chesapeake Bay impact structure (abstract). Workshop - Impact Craters as Indicators for Planetary Environmental Evolution and Astrobiology, Östersund, Sweden, 8-14 June 2006.

\section{Authors}

Gregory S. Gohn, U.S. Geological Survey, 926A National Center, Reston, Va., 20192, U.S.A., e-mail: ggohn@usgs.gov Christian Koeberl, University of Vienna, Vienna, Austria

Kenneth G. Miller, Rutgers University, Piscataway, N.J., U.S.A.

Wolf Uwe Reimold, University of the Witwatersrand, Johannesburg, South Africa, and Humboldt University, Berlin, Germany

and the Scientific Staff of the Chesapeake Bay Impact Structure Deep Drilling Project

\section{Related Web Links}

http://chesapeake.icdp-online.org/ http://chicxulub.icdp-online.org/

\section{Figure Credits}

Fig. 1 and 2: courtesy of CBIS Deep Drilling Project Fig. 3 and 4: from David Powars, USGS 